\title{
Middle Holocene environmental change and archaeology in coastal wetlands: further implications for our understanding of the history of Taxus woodland
}

Article

Accepted Version

Batchelor, C. R., Branch, N. P., Carew, T., Elias, S. E., Gale, R., Lafferty, G. E., Matthews, I. P., Meddens, F., VaughanWilliams, A., Webster, L. A. and Young, D. S. (2020) Middle Holocene environmental change and archaeology in coastal wetlands: further implications for our understanding of the history of Taxus woodland. The Holocene, 30 (2). pp. 300-314. ISSN 0959-6836 doi:

https://doi.org/10.1177/0959683619883028 Available at https://centaur.reading.ac.uk/87184/

It is advisable to refer to the publisher's version if you intend to cite from the work. See Guidance on citing.

To link to this article DOI: http://dx.doi.org/10.1177/0959683619883028

Publisher: Sage Publications

All outputs in CentAUR are protected by Intellectual Property Rights law, including copyright law. Copyright and IPR is retained by the creators or other copyright holders. Terms and conditions for use of this material are defined in 
the End User Agreement.

www.reading.ac.uk/centaur

\section{CentAUR}

Central Archive at the University of Reading

Reading's research outputs online 


\title{
Middle Holocene environmental change and archaeology in coastal wetlands: further implications for our understanding of the history of Taxus woodland
}

Batchelor, C.R. ${ }^{1}$, Branch, N.P. ${ }^{1}$, Carew, T. ${ }^{2}$, Elias, S.E. ${ }^{3}$, Gale, R. ${ }^{4}$, Lafferty, G.E. ${ }^{1}$, Matthews, I.P. ${ }^{3}$ Meddens, F. ${ }^{5}$, Vaughan-Williams A. ${ }^{6}$, Webster, L. ${ }^{3}$ \& Young, D.S. ${ }^{1}$

\author{
${ }^{1}$ School of Archaeology, Geography and Environmental Science, University of Reading, UK \\ 271 Burghley Road, London, UK \\ ${ }^{3}$ Department of Geography Royal Holloway, University of London, UK \\ ${ }^{4}$ Bachefield House, Kimbolton, Leominster, Herefordshire \\ ${ }_{5}^{5}$ Pre-construct Archaeology Limited, Brockley, London, UK \\ ${ }^{6}$ Tor Cottage, Scarthin, Cromford, Derbyshire
}

\section{Abstract}

A radiocarbon-dated multi-proxy palaeoenvironmental record from Beckton in the Lower Thames Valley, Southern England has permitted a detailed reconstruction of human activities and environmental change during the Middle Holocene. Peat accumulation occurred over river terrace gravels from ca. $7200-6600$ until at least $3450-3240$ cal BP and in the later period a trackway and platform structure provide unequivocal evidence for human exploitation of the floodplain environment during the Bronze Age. The site is unique in offering the first certain evidence of the utilisation of Taxus in in the construction of a wooden prehistoric platform. Across north-west Europe during the Middle Holocene, the colonisation of Taxus on peat is well-documented; at Beckton it occurred between ca. 5220-4940 to 4410-4220 cal BP. The research provides important insights into the former distribution of Taxus, and reasons for its expansion and decline during the Holocene, which has relevance to present day concerns over the conservation and management of Taxus woodland. Abandonment of the site occurred in response to environmental change to wetter conditions. The study employed multi-proxy analyses, including pollen, plant and wood macrofossils, and uniquely Coleoptera; Coleopteran analysis has significant potential to enhance understandings of environmental change and human-environment interactions in coastal wetland research. 


\section{Keywords}

Archaeology, environmental change, relative sea level, Taxus (yew), vegetation history, tephra

\subsection{Introduction}

Today, Taxus baccata (L.) populations are relatively rare across its natural geographical range, and more significantly, are declining with a lack of natural regeneration (e.g. Thomas \& Polwart, 2003;

Deforce \& Bastiaens, 2007; Ruprecht et al., 2010; Linares, 2013; Iskulo et al., 2016). Protected areas and priority habitat status (EU Habitat Directive 92/43/EEC) have been established to conserve the natural distribution of the species (e.g. Svenning \& Magärd, 1999; Thomas \& Polwort, 2003; Mysterud \& Østbye, 2004; Iskulo et al., 2016). The reduction in population is due to a combination of human pressures, grazing, temperature, competition (caused by excessive shade) and the dioecious nature of the species (e.g. Svenning \& Magärd, 1999; Thomas \& Polwort, 2003; Mysterud \& Østbye, 2004; Iskulo et al., 2012). Palaeoecological research can provide an important insight into the former distribution and pressures on Taxus populations, which is relevant to current concerns over declining levels and attempts to improve conservation and management of the species (Iskulo et al., 2016).

The presence of Taxus on the coastal wetlands of the Lower Thames Valley, Southern England and other parts of northwest Europe during the Middle Holocene is now well known (e.g. Beckett \& Hibbert, 1979; Waller, 1994a; O'Connell \& Molloy, 2001; Delahunty, 2002; Deforce \& Bastiaens, 2007; Batchelor, 2009; Branch et al., 2012; Deforce et al., 2014; Waller \& Early, 2015). Little is known however about the reason(s) for its colonisation, decline and former distribution on coastal wetlands. Branch et al., (2012) outlined the potential mechanisms involved, especially the importance of changes in peatland hydrology linked to relative sea level change. This new study examined in greater detail the interaction between vegetation succession and prehistoric human activities, thus permitting an evaluation of the role of human communities in the decline of Taxus.

The site at Beckton is located on the margins of the floodplain, adjacent to the geological and topographical boundary of the East Tilbury Marshes Gravel terrace (Gibbard, 1995), and approximately midway between the Lea and Roding tributaries. A detailed account of the archaeological findings is provided by Carew et al. (2009). Two trenches were excavated at the site 
(Figure 1c), both containing a gravel surface overlain by approximately $2 \mathrm{~m}$ of peat, capped by $1.5 \mathrm{~m}$ of fine grained alluvium and top soil (Figure 2a). In Trench 1, abundant well-preserved wood was recorded towards the top of the peat including the wooden platform and brushwood trackway (Figure $2 b)$. The platform lay on a peat surface radiocarbon dated $4230-3890$ cal BP $(-1.85$ to $-1.87 m$ OD; Table 1), whilst three determinations on timbers from the structure itself $(-1.85 m$ to $-1.79 m$ OD) give a combined age range of 3980-3580 cal BP (early Bronze Age). The trackway was located on a peat surface dated $4240-3920$ cal BP (-1.78 to $-1.80 \mathrm{~m} \mathrm{OD})$, with two dates from the structure itself giving a combined age range of 3550-3180 cal BP (late Bronze Age). A number of similar structures have been discovered along the floodplain of the Lower Thames Valley (e.g. Thomas and Rackham, 1996; Meddens, 1996; Divers, 1996; Figure 1a). With the exception of a Neolithic structure at Belmarsh West (Hart, 2010) and Silvertown Fort Street (Crockett et al., 2002), these date broadly to the Bronze Age between 4000 and 3000 cal BP, and are generally located towards the top of a thick horizon of terrestrial peat, which is overlain by fine-grained alluvium representative of flooding.

\section{$2.0 \quad$ Methods}

Due to the presence of the archaeological structures, Trench 1 was selected for detailed laboratory analysis. Column and bulk samples were taken through the sequence on the northern face of Trench

1 (Figure 2). Two separate columns were taken at the height of the trackway; one through it $(<6\rangle)$, and one on the western side $(<4>)$. Lithostratigraphic analysis was carried out on both columns to establish the presence of any variations in the sequence caused by the trackway. The column samples were cleaned and described (Troels-Smith, 1955), and heights above mean sea level noted (British Ordnance Datum - m OD; Figure 2). The organic matter content was determined using the loss-on-ignition method (Bengtsson \& Enell, 1986).

Pollen grains and spores were extracted following standard procedures (Branch et al., 2005a), and identified using type collections, keys and photographs (Moore et al., 1991; Reille, 1992). Poaceae grains were devided into wild or domesticated on the basis of grain size and annulus diameter (Andersen, 1979). The resultant Poaceae $>40 \mu \mathrm{m}$ category combines all cereal types and wild grasses. A total of 300 pollen grains (excluding aquatics and spores) were recorded for each sample. The results are expressed as a percentage of total land pollen (trees, shrubs, herbs) prepared using 
Tilia software (Grimm, 2004). The percentage pollen diagram was sub-divided into four local pollen assemblage zones (LPAZ) using numerical methods (CONISS). Pollen nomenclature follows Moore et al. (1991).

The plant macrofossils (seeds and fruits) were extracted from the bulk samples by sub-sampling a standard volume of sediment $(250 \mathrm{ml})$ and wet sieving them through $4 \mathrm{~mm}, 2 \mathrm{~mm}, 1 \mathrm{~mm}$ and $300 \mu \mathrm{m}$ mesh sieves. The plant macrofossils were identified using type collections, keys and photographs (e.g. Berggren, 1981a, b; Anderberg, 1994). Waterlogged wood was extracted from separate samples associated with the archaeological structures. They consisted mostly of fragments of roundwood of various diameters. The wood was generally degraded and/or compressed, and in some instances it was not possible to provide a positive identification or accurate ring count. A minimum of 10 fragments were counted from each sample where available. Selection was based upon diameter (to represent roundwood from across the range) and morphology (to include fragments with several external characteristics). Thin sections were prepared using standard methods (Gale and Cutler, 2000), and the wood structure matched to reference slides. Plant nomenclature for wood and plant macrofossil remains follows the Flora Europaea as summarised in Stace (1997). Coleopteran remains were obtained from the bulk samples by wet sieving $(1000-4000 \mathrm{ml})$ over a $300 \mu \mathrm{m}$ mesh, concentrated by paraffin flotation (Atkinson et al., 1987).

Nine AMS radiocarbon determinations were made on plant macrofossils (seeds and wood) or bulk peat from the trackway and associated lithostratigraphic sequence, while a further five were undertaken on plant macrofossils from the platform (Figures 2, 3; Table 2). The radiocarbon determinations were calibrated using OxCal version 4.2.4 (Bronk-Ramsey, 1995, 2001, 2007) and Intcal13 (Reimer et al., 2013). The full calibrated age ranges (rounded to 10 years) are quoted as 'cal BP'.

An age model was generated within OxCal using a ' $P$-sequence' algorithm and $k$ factor of 100 (Bronk Ramsey, 2007; Blockley et al., 2007). The model placed boundaries at four key lithostratigraphic changes: (1) peat accumulating between $-3.64 \mathrm{~m}$ to $-1.78 \mathrm{~m}$ OD; (2) peat spanning the trackway ($1.78 \mathrm{~m}$ to $-1.67 \mathrm{~m} \mathrm{OD})$; (3) peat accumulating during a significant decrease in organic matter content, 
immediately above the trackway (-1.67m to $-1.53 \mathrm{~m}$ OD; Figure 3$)$, and (4) peat accumulating between $-1.53 \mathrm{~m}$ and $-1.24 \mathrm{~m}$ OD. Generation of the final model was an iterative process; when all of the radiocarbon dates were included, poor agreement was evident in the upper 5 radiocarbon dates (Beta180310 to Wk-19034). The quality of individual samples was assessed. Where dates were from deposits representing mainly autochthonous material and stable depositional conditions they were considered likely to be more robust and retained, whilst dates originating from zones of human disturbance (e.g. the trackway) or where alluvial influence was prominent were considered more likely to suffer from complex transport and burial histories, and thus excluded from the final model (Table 1). While this procedure has the potential to be subjective, the date rejection criteria used relies on sound stratigraphic and sedimentological principles to independently assess each date. This procedure generated a model with high agreement indices and thus was used to interpolate age ranges at $10 \mathrm{~cm}$ intervals through the peat and for each LPAZ boundary; the full calibrated age ranges (rounded to 10 years) are quoted in italics as 'cal BP'. It is highlighted that the modelled ages become too imprecise for use above the trackway and the chronological inferences drawn from these intervals should be considered with this caveat in mind. The final model can be viewed in the Supplementary Data.

In order to assess the robustness of the final age model and to provide additional chronological information, the sequence was studied for its cryptotephra content using the methods outlined in Blockley et al. (2005). This identified low concentrations of both colourless and brown tephra shards in four broad zones: -3.60 to $-3.50 ;-3.30$ to $-3.10 ;-3.00$ to -2.90 ; and -2.30 to $-2.10 \mathrm{~m}$ OD. The upper two zones had shard concentrations of below 2 shards $/ \mathrm{cm}^{3}$ of sediment and were not pursued further, while the lower zones had higher concentrations (16 and 27 shards $/ \mathrm{cm}^{3}$ of sediment, respectively). The lower two intervals were prepared and analysed using WDS-EPMA chemical analysis. Diagnostic chemical data was only obtained on the upper peak $(-2.99 \mathrm{~m}$ OD) which indicated that the tephra was a sub-Alkali basalt derived from the Katla volcano in Iceland. However, the Katla volcano is highly productive with over 208 basaltic eruptions occurring during the Holocene, many with identical major and trace element chemical compositions (Larsen et al., 2001; Óladottir et al. 2008; Lane et al., 2012); hence the tephra was not useful in either testing or refining the chronology of the lithostratigraphic sequence at Beckton. Nevertheless, on the basis of the existing radiocarbon chronology the tephra can be broadly dated to between 7000 and 6000 cal BP, and significantly, represents the first example 
of middle Holocene tephra deposition in the Thames basin. The full findings will be reported elsewhere.

\subsection{Lithological interpretation and results of the radiocarbon dating}

Below $-3.64 m$ OD, gravel and sandy-clay deposits were recorded during the archaeological excavations (Figure 2). These sediments represent the upper surface of the Late Devensian Shepperton Gravel, which was deposited under high energy fluvial conditions in a braided river environment. This surface reduces in height from north to south across the site $(c a$. $-3.60 \mathrm{~m}$ to $-6.00 \mathrm{~m}$ OD) as would be expected from the position of the gravel terrace to the north (Carew et al., 2009).

Between -3.64 and $-1.74 m$ OD, the formation of wood peat represents the creation of semi-terrestrial conditions. The results of the radiocarbon dating and age-depth modelling suggest this transition took place around 7190-6620 cal BP (Figure 3; Table 1). This transition corresponds to a regional reduction in the rate of sea level rise from 2.6 to $0.8 \mathrm{~mm} / \mathrm{yr}$ from ca. $8000 \mathrm{cal} \mathrm{BP}$, which caused widespread peat formation along the Lower Thames Valley between ca. 6800 and 5800 cal BP (Devoy, 1979, 1982; Sidell, 2003). During peat formation, the surface was prone to flooding, resulting in $>20 \%$ input of mineral matter; between -2.84 and -2.24m OD (Unit 3; ca. 5740-5500 to 4860-4570 cal BP) inundation appears to have occurred more regularly.

The trackway is recorded in the sampled sequence between -1.74 and $-1.67 \mathrm{~m}$ OD on a surface of high organic matter content (75\%; 4140-3900 cal BP), contemporaneously with the age upon which the platform was constructed (4230-3890 cal BP). Immediately above the trackway, the presence of clay and low organic-matter values indicate inundation between -1.67 and $-1.50 \mathrm{~m}$ OD, prior to a temporary return to drier conditions between $-1.50 \mathrm{~m}$ and $-1.24 \mathrm{~m}$ OD. Little variation in lithostratigraphy is recorded between columns $<6>$ and $<4>$ suggesting that the trackway had little impact upon peat accumulation (Figure 3). Above $-1.24 \mathrm{~m}$ OD to the top of the sequence, the deposition of clay, rich in detrital plant remains represents the transition to fluvial, possibly estuarine conditions at the site. Unfortunately, the chronology of events above the trackway (3460-3240 cal BP) is uncertain. However, the timing of final peat inundation is thought likely to be contemporaneous with other local sites around 2500 cal BP (Figure 1b): Beckton Nursery (2700-2180 cal BP; Divers, 1995), Beckton 3D 
(2700-2150 cal BP; Meddens, 1996), Beckton Tollgate (2330-2000 cal BP; Tamblyn, 1994), East Beckton District Centre (2670-2150 cal BP; Jarrett, 1996) and East Ham FC (2300-2005 cal BP; Scaife, 2001). The results indicate that the entire peat sequence spans the late Mesolithic to late Bronze/early Iron Age cultural periods.

\subsection{Results and interpretation of the palaeobotanical analyses \\ 4.1 Pollen analysis}

LPAZ GWB-1 indicates that between -3.64 and $-2.46 \mathrm{~m}$ OD (7190-6620 to $5220-4940$ cal BP) the dryland vegetation was dominated by mixed-Quercus dominated woodland with Tilia, Ulmus, Corylus, lesser quantities of Fraxinus and Betula; towards the end of the zone Taxus is recorded (Figure 4; Table 1). The most significant change in dryland vegetation was recorded around $7110-6560$ cal BP ($3.60 \mathrm{~m}$ OD), before which high percentage values of Tilia pollen suggest it was dominant or codominant with Quercus. In addition, whilst Ulmus was a minor component of the dryland vegetation, pollen percentage values decline to near absence indicating a population reduction between ca. 6150 6000 and $6030-5810(-3.06$ to $-2.98 m$ OD).

The decline in Ulmus pollen percentage values, occurs however around the time of an increase in taxa suggestive of improved light penetration to the ground surface (including Poaceae, Plantago lanceolata, Chenopodium type, Poaceae $>40 \mu \mathrm{m}$, Hedera) between 5890-5650 and 5570-5510 cal BP $(-2.90$ and $-2.82 m$ OD). At this time, during the early stages of paludification, the site was located much closer to the floodplain edge than the $150 \mathrm{~m}$ distance currently indicated by British Geological Survey mapping (Figure 1a). As a consequence of this closer proximity, there is greater potential that the vegetation change occurred on the adjacent dryland (e.g. Hjelle, 1998; Bunting et al., 2004). However, due to taphonomic issues specific to coastal wetlands (including the difficulties of distinguishing the environment of origin of many herbaceous taxa (e.g. Waller, 1998; Waller et al., 2005) and of splitting cereal pollen from that of wetland grasses (Andersen, 1979; Waller \& Grant, 2012; Perez et al., 2015)) it is possible some of these pollen taxa originated from plants growing on the floodplain. Furthermore, plants of the Chenopodiaceae family may be split into two broad groups, those associated with brackish and marine environments such as Salsola kali, and those commonly found in waste places and the edges of arable fields on dryland, such as Chenopodium album. Thus, 
the pollen values of Chenopodium type recorded may indicate the growth of saltmarsh plants (and therefore a brackish water influence) on the wetland rather than more open conditions on the dryland. It is also noteworthy that the decline of Ulmus occurred during a time of enhanced Alnus pollen values, and there is a possibility that the decline is the result of reciprocal changes in percentage pollen values.

The wetland was dominated by taxa analogous to that of present-day fen carr woodland, found in lowlying areas that are waterlogged for much of the year (e.g. Wheeler, 1980). The woodland was dominated by Alnus glutinosa with some Salix, both of which are common to these wetland ecosystems. Fraxinus, Betula and Corylus may also have occupied the wetland, together with Rosa, Prunus and Lonicera periclymenum. The ground flora would have consisted of the following herbs, aquatics and ferns: Poaceae, Cyperaceae, Apiaceae, Ranunculus, Menyanthes trifoliata, Sparganium and Typha latifolia, Dryopteris and Polypodium vulgare.

The transition to LPAZ GWB-2 is defined by rising percentages of Taxus pollen, representing its colonisation of the peat surface from $5220-4940$ cal BP $(-2.46 \mathrm{~m}$ OD). The pollen record indicates that Taxus became an important component of the wetland woodland dominated by Alnus. Otherwise, much of the woodland composition remained unchanged from LPAZ GWB-1, with the exception of the expansion of Fraxinus with Taxus, and a decline in the number of herbaceous pollen taxa recorded. Neither of these findings is unexpected; Taxus and Fraxinus have been recorded as separate subcommunities in former Alnus dominated woodland on the nearby Erith foreshore (Seel, 2001), whilst the field layer beneath Taxus is known to be sparse due to the dense shade produced by its canopy (Seel, 2001; Thomas and Polwart, 2003). The presence of Taxus suggests that the peat surface was drier during this period since it is unlikely to have grown on unconsolidated very wet peat (Thomas and Polwort, 2003); an interpretation supported by a reduction in aquatic pollen.

The dryland continued to be dominated by mixed deciduous woodland through much of LPAZ GWB-2. However, towards the top of the zone, changes in vegetation composition are recorded on both the wetland and dryland. Taxus undergoes a long-term decline from $4410-4220 \mathrm{cal}$ BP on the wetland, towards the end of which Quercus and Tilia decline on the dryland from 4160-3930 cal BP. The 
decline of Taxus resulted in an apparent return to a wetland woodland canopy dominated by Alnus with Salix. Minimal values of Poaceae, Cyperaceae and aquatic taxa do not suggest this occurred as a consequence of wetter conditions, although the possibility of paludification cannot be discarded as a possible causal factor (e.g. Waller, 1994b; Grant et al., 2011). However, the age of the platform (4240$3890 \mathrm{cal} \mathrm{BP}$ ) and later trackway (3460-3240 cal BP) do provide unequivocal evidence for the presence and impact of human activity within the immediate area of the site at this time.

LPAZ GWB-3 commences immediately above the trackway structure (sometime after 3460-3270 cal $\mathrm{BP})$ and is characterised by significant changes in pollen stratigraphy: (1) the decline of Alnus; (2) an increase in the number of herbs and ferns indicating more open conditions (e.g. Poaceae, Plantago lanceolata and Pteridium aquilinum); (3) an increase in pollen of light demanding shrubs (e.g. Hedera), and (4) an increase in pollen taxa indicative of aquatic vegetation communities (e.g. Sparganium, Cyperaceae and most likely Poaceae). The pollen-data provides unequivocal evidence that the vegetation community on the peat immediately overlying the trackway was significantly different to that beneath: the decrease of Alnus together with increasing Cyperaceae, Sparganium and most likely Poaceae (e.g. Phragmites australis) indicates retrogressive succession in response to wetter conditions. Increasing pollen values of Chenopodium type may also indicate that local environmental conditions were becoming more brackish rather than exclusively freshwater. Of particular importance here is the interpretation of the Poaceae $>40 \mu \mathrm{m}$ pollen grains which might be used to infer nearby arable cultivation. However, as highlighted above, this group includes both cereals and wild grasses (Andersen, 1979); previous studies have indicated the association of these grains with other wetland herbaceous and aquatic taxa (e.g. Poaceae, Cyperaceae, Sparganium) means that at least a large proportion of them represent wild grasses found in wetland habitats (e.g. Glyceria sp.) (Waller \& Grant, 2012; Perez et al., 2015). Furthermore, due to the poor dispersal characteristics of cereal pollen grains, the $>5 \%$ pollen values recorded would require substantial cultivation proximal to the site.

Midway through the zone (-1.50 to $-1.38 \mathrm{~m}$ OD), an increase in Alnus and decline of herbaceous and aquatic taxa suggests a re-expansion of woodland on the wetland. This period is short-lived with a second, permanent decline in Alnus occurring at the transition into LPAZ GWB-4 (which also coincides with the transition from peat to clay). The decline of Alnus woodland is accompanied by the same 
increase of shrub, herbaceous and aquatic taxa as that recorded at the beginning of LPAZ GWB-3. However, in this case, the presence of Armeria maritima with higher values of Chenopodium type provides stronger evidence for brackish water conditions. In addition, Pteridium aquilinum and Pinus are recorded in high quantities; these palynomorphs are commonly over-represented within the sediments of such environments due to their ability to travel long distances (by fluvial and/or aeolian means; Campbell, 1999).

\subsection{Plant macrofossil and wood analyses}

Plants commonly found within fen carr woodlands dominate the plant macrofossil record (Figure 5). Although some samples had no macrofossil preservation, the common occurrence of Alnus glutinosa and Rubus sp. with sporadic Betula pendula/pubescens, Corylus avellana, Vaccinium sp., Sambucus nigra and Prunus indicates a mosaic of woodland with an understorey of shrubs. Similarly, a wide range of herbaceous taxa are recorded including Ranunculus sp., Solanum dulcamara, Apiaceae cf Oenanthe sp. and various Cyperaceae. The only noticeable change in assemblage occurs between 1.78 and $-1.39 \mathrm{~m}$ OD (from 4140-3900 cal BP; level with and above the trackway) in which an increase in herb and aquatic taxa suggest wetter conditions (including Sparganium sp., Eleocharis palustris and Polygonum hydropiper). Another notable occurrence is the presence of Atriplex/Sueada sp. seeds at 2.56 to $-2.35 \mathrm{~m}$ OD (ca. $5430-4830 \mathrm{cal} \mathrm{BP}$ ) indicating the growth of saline plants or disturbed ground taxa. The wood macrofossil data (Figure 2b; Carew et al., 2009) confirm the predominant growth of Alnus glutinosa on the wetland with Taxus, Fraxinus excelsior, and Betula sp.

\subsection{Results and interpretation of the coleopteran analysis}

Three local coleopteran assemblage zones (LCAZ-1 to 3) have been defined (Table 2; Figure 6). Throughout the sequence, pools of stagnant, vegetation-rich water were present at or near to the site. This is indicated by the presence of a diverse range of species, such as the water scavenger beetles Cercyon ustulatus, Hydrobius fuscipes, Octhebius minimus and Hydraena testacea. Predaceous diving beetles such as Colymbetes fuscus suggest that some vegetation-free stretches of open water must always have been available for colonisation (Friday, 1988; Koch, 1989). This in turn indicates that some of the local aquatic habitats consisted of larger, more permanent ponds and not temporary pools. 
During LCAZ-1 (ca. 6920-6440 to $6030-5810$ cal BP; -3.54 to $-2.96 \mathrm{~m}$ OD), the site was located in richly vegetated deciduous ancient woodland, including Quercus, Tilia, Ulmus, Betula and Acer. This is indicated by the presence of bark beetles such as Scolytus multistriatus, Scolytus mali, Kissophagus hederae, Dryocoetinus villosus, Ernoporus caucasicus. The presence of dead standing deciduous wood is indicated by the throscid beetle Trixagus dermestoides whose larvae develop in wood, the silvanid beetle Silvanus unidentatus that lives under Quercus bark, and weevils Rhyncolus punctulatus and Coeliodes erythroleucos that live in Quercus. This picture is atypical of other floodplain sites where the ground is usually too damp to support mature tree species.

The transition into LCAZ-2 (ca. $6030-5810$ to $4160-3930$ cal BP; -2.96 to $-1.78 \mathrm{~m}$ OD) is characterised by the reduction of dryland woodland and appearance of wetland habitats. This is consistent with evidence for ongoing paludification and is supported by the development of Alnus carr throughout this interval. There is evidence for the development of Alnus carr through this interval. Leaf beetles such as Chrysomela aenea and Plagiodera versicolora provide evidence for the presence of Alnus and Salix, whilst the growth of Phragmites, Cyperaceae and Oenanthe is indicated by aquatic plantfeeding beetles Plateumaris braccata and Prasocuris phellandrii. Lemna minor is indicated by the aquatic weevil Tanysphyrus lemnae.

After $4160-3930$ cal BP (-1.78 to $-1.01 \mathrm{~m} \mathrm{OD;} \mathrm{LCAZ-3),} \mathrm{woodland} \mathrm{appears} \mathrm{to} \mathrm{recede,} \mathrm{with} \mathrm{evidence} \mathrm{for}$ the expansion of grassland and open, sunny areas indicated by species such as Trechus quadristriatus, Pterostichus nigrita and Bembidion guttula (Koch, 1989; Lindroth, 1974). This corresponds to a large increase in mineral sediment input at $-1.78 \mathrm{~m}$ OD, which suggests widespread flooding at the site. The evidence for a change to more open woodland is supported by the appearance of the weevil Bagous argillaceous in the upper part of the sequence, which feeds on Poaceae (Alexander, 1994). LCAZ-3 is also characterized by the appearance of the long-toed water beetle Esolus parallelopipedus, a river and stream species which prefers clean stones and low silt conditions (Koch, 1989).

\subsection{Discussion}




\subsection{Dryland environmental change in the Lower Thames Valley}

The close proximity of the site to the wetland edge has permitted reconstruction of the prehistoric vegetation on the dryland. The palaeobotanical records strongly suggest that dryland woodland, dominated by Tilia and Quercus with Ulmus and Corylus initially occupied the site prior to peat formation, as indicated by very high percentage values of Tilia pollen (which is entomophillous) and insects monophagous to Tilia and Quercus. These pollen and insect indicators rapidly reduce signifying the retreat of dryland woodland in response to peat formation (paludification). The cause(s) of the middle Holocene Tilia decline in the UK have been comprehensively reviewed by Grant et al. (2011), and the cause of this early event at Beckton is a clear example of paludification Type II: a rapid decline associated with a transition from dryland to peat formation (see also Waller, 1994b).

The low percentages of Ulmus suggest that it was a minor component of the woodland cover. However, due to the dense cover of wetland and dryland woodland, the under-representation of Ulmus might be related to pollen filtration. Despite this, a reduction in Ulmus pollen is recorded between ca. $6150-6000$ and $6030-5810$. The event is considered significant because it coincides with the welldocumented 'Ulmus decline' in NW European pollen records (Parker et al., 2002) and the Lower Thames Valley (e.g. Devoy, 1979; Wilkinson, 1988; Wilkinson et al., 2000; Batchelor et al., 2014). The reasons for this decline have been of some debate with the following hypotheses proposed: (1) climate change to cooler conditions (e.g. Smith, 1981); (2) soil deterioration (Peglar and Birks, 1993); (3) competitive exclusion (e.g. Huntley and Birks, 1983; Peglar and Birks, 1993); (4) human interference with natural vegetation (e.g. Scaife, 1988; Lamb and Thompson, 2005), (5) disease (e.g. Perry and Moore, 1987; Girling, 1988; Waller, 2013), and (6) multiple causes (e.g. Parker et al., 2002; Batchelor et al., 2014).

The event at Beckton is preceded by occurrences of the elm bark beetle Scolytus multistriatus. In modern contexts, S. scolytus and S. multistriatus are the beetles responsible for carrying the fungus Ceratocystis (Ophiostoma) ulmi that causes disease. Whilst not monophagous on Ulmus and considered the less reliable indicator, the presence of Scolytus multistriatus prior to, and during the decline may therefore represent potential evidence for a disease-caused decline, especially when combined with further similarly dated insect records of S. scolytus in London at Hampstead Heath 
(Girling, 1988), Old Seager Distillery, in Kent at Horton Kirby Paper Mill (Batchelor et al., 2014), and further afield at Red Moss of Candyglirach, Aberdeen (Clark \& Edwards, 2004). However, it is also argued that the occurrence of $S$. scolytus / multistriatus only demonstrates the presence of a suitable habitat, and evidence for the growth of Ulmus, either dead, or growing under stressed conditions; not for the presence of disease itself (Bevan, 1987; Robinson, 2000; Waller, 2013).

An increase in the number of light-loving herbs and shrubs (including Poaceae, Plantago lanceolata, Poaceae $>40 \mu \mathrm{m}$ and Hedera) occurs immediately after the decline between 5890-5650 and 55705510 cal BP, suggestive of Neolithic temporary land clearance for agricultural purposes. This interpretation is supported by unequivocal archaeological evidence approximately $200 \mathrm{~m}$ to the northeast of the site on dryland, where a scatter of pottery, struck and burnt flint and a considerable quantity of carbonised processed grain (Triticum dicoccon and possibly T. monococcum) dated to 5890-5320 cal BP were recorded (Stafford et al., 2012).

The evidence from Beckton therefore contributes to the multi-causal model for the Ulmus decline. However, simply referring to this model does not take into account the precise relationships between the different causal factors at individual sites (e.g. primary / secondary causes and consequences), that led to the decline (see Waller, 2013; Batchelor et al., 2014). Due to the significant number of palaeoenvironmental records in the Lower Thames Valley, a classification system was recently proposed enabling such a categorisation (Batchelor et al., 2014). Within this system, Beckton and Hampstead Heath were placed within the same category as they both contain evidence for Ulmus growing under stressed conditions (possibly suffering the effects of disease) due to the presence of $S$. scolytus/multistriatus, prior to its decline from the local environment, with, or followed by archaeological/palaeoecological evidence for human activity. At Hampstead Heath, S. scolytus predates the decline, although the precise temporal relationship is uncertain, whilst the decline itself occurs with and is post-dated by coleopteran and palynological evidence for human activity (Girling \& Grieg, 1985; Girling, 1988; Parker et al., 2002).

After the decline of UImus, it is considered likely that Taxus colonised the dryland prior to expanding onto the peat surface (see 6.2) for the following reasons: (1) the very low concentrations of pollen 
recorded may suggest distal growth; (2) the present-day preference of Taxus is for dry and well drained soils, and (3) openings produced within the woodland by the reduction of Ulmus would have represented opportunities for the colonisation of Taxus which is recognised as a pioneer species (Tittensor, 1980). Support for this argument also comes from a number of Irish records that show Taxus pollen percentages increasing shortly after episodes of temporary land clearance associated with an Ulmus decline (e.g. O'Connell et al, 1988; Mitchell, 1990; O'Connell and Molloy, 2001; Huang, 2002; Molloy and O'Connell, 2004; Lamb and Thompson, 2005). If this is the case, it suggests that the initial colonisation of Taxus may have been influenced by human activity at Beckton.

At Beckton, the decline of dryland woodland is indicated by the synchronous decline of Tilia and Quercus shortly after $4160-3930$ cal BP. The date of this decline is consistent with that recorded at other sites in the Lower Thames Valley (e.g. Thomas \& Rackham, 1996; Wilkinson et al., 2000; Branch et al., 2012) and UK (Grant et al., 2011), occurring between ca. 5000 and 3000 cal BP. The decline is contemporaneous with evidence of human activity and a change in vegetation on the floodplain; initially Alnus dominated and was succeeded by a large expansion of herbs and aquatics indicative of wetter conditions. Waller \& Grant (2012) argue that such abrupt, simultaneous changes in pollen stratigraphy (which are a common feature in pollen diagrams from the Lower Thames Valley) are not good indicators for a reduction in the abundance of Tilia. This is because, prior to vegetation change on the floodplain, any evidence for dryland clearance will be masked by the fen woodland, whilst difficulties in determining the environment of origin of many herbs (including Poaceae $>40 \mu \mathrm{m}$ ) hinders the identification of such events after the decline. Higher resolution pollen analysis through this part of the sequence may have enabled the causes of the Tilia decline to be considered further, but it is categorised here as an example of wetland processes and a reciprocal change in pollen representation (Grant et al., 2011).

\subsection{The history of Taxus woodland in the Lower Thames Valley}

The pollen-stratigraphic record indicates that the main expansion of Taxus woodland occurred on the peat surface at Beckton around 5220-4940 cal BP (-2.46m OD). Waterlogged wood identifications were not carried out on the main sequence, and macrofossil and insect remains are absent, most likely as a consequence of factors specific to Taxus including: (1) that there are no known insect taxa 
exclusively associated with Taxus (Lattin, 1998; Daniewski et al., 1998; Hageneder, 2007), and (2) that the late sexual maturity and dioecious nature of the tree may have reduced the number of seeds produced (Thomas \& Polwart, 2003). However, the high pollen percentage values recorded at the site in tandem with the identification of trees in the peat at Beckton Nursery (Divers, 1995), A13 Woolwich Manor Way (Gifford and Partners, 2001), Beckton Alp (Truckle and Sabel, 1994), Beckton Tollgate (Tamblyn, 1994), East Beckton District Centre (Jarrett 1996) and East Ham Football Club (Scaife, 2001; Figure 1) indicate that Taxus formed a mixed wetland woodland community with Alnus for which there are few comparable palaeobotanical records across north-western Europe (e.g. Godwin, 1975; Beckett and Hibbert, 1979; Orme and Coles, 1989; Waller, 1994a; O'Connell and Molloy, 2001; Delahunty, 2002; Deforce and Bastiaens, 2007; Deforce et al., 2014; Waller and Early, 2015) and, significantly, for which there is no known modern analogue in the UK (Seel, 2001).

Taxus is now known to have been an important component of the Alnus dominated woodland on the peat surface of the Lower Thames Valley, spanning from at least the East India Docks (Pepys, 1665) in the west to Aveley Parish and Erith Forest in the east (Wilkinson and Murphy, 1995; Seel, 2001), according to multi-proxy palaeoenvironmental investigations. The importance of increasing knowledge and understanding of the timing and causes of this colonisation and decline have recently been highlighted by Branch et al. (2012) who propose five possible mechanisms: (1) variations in peat surface hydrology; (2) variations in the rate of relative sea level rise; (3) human activity; (4) climatic change, and (5) genetic variability.

At Beckton, the expansion of Taxus appears to occur during a period of drying peat surface conditions as indicated by rising organic matter values and a decrease in clay content (Figure 3). The expansion of Taxus at the site is analogous in date and nature to that of Hornchurch Marshes to the east (Branch et al., 2012), suggesting that regional factor(s) influenced this event either by driving changes in peat hydrology (e.g. relative sea level change) or upon Taxus directly (climatic change). However, it is of note that at Beckton the same drier hydrological conditions were present during the early stages of peat formation, when Taxus was not. 
Taxus underwent a long-term decline at Beckton commencing from $4400-4230 \mathrm{cal} \mathrm{BP}$, and continuing until shortly after $4160-3930$ cal BP. The age of the platform structure (3980-3580 cal BP), and use of Taxus in its construction provides the first unequivocal evidence for its direct use by prehistoric people in the Lower Thames Valley. However, even with a lack of artefact remains of Taxus elsewhere, the impact of humans upon its decline should not be underestimated. Many palaeoenvironmental and archaeological records indicate that the wetland had a role in the rearing of domesticated animals. These include the presence of a cow's tooth at Beckton, domesticated animal bone at Atlas Wharf (Lakin, 1998), East Beckton District Centre (Jarrett, 1996) and Tesco's Swedish Wharf (Chew, 1994; Meddens, 1996), dung beetles at Beckton, St Paul's Academy (Hawkins, 2005), Bridge Road Rainham (Grattan 1991), and Bellot Street (Branch et al., 2005b), and a causeway at Hays Storage, Dagenham. Ecological evidence demonstrates that these animals can become tolerant to the toxicity of Taxus, and that the tree is highly susceptible to, and disadvantaged by such browsing (Kelly, 1981; Mitchell, 1988; Hannon and Bradshaw, 1989; Mitchell, 1990; Tittensor, 1980; Mysterud and Østbye, 2004; Hageneder, 2007). The new results from Beckton indicate that the decline in Taxus may have been more closely linked to human activity, rather than changes in peat hydrology (linked to relative sea level) (see Branch et al., 2012).

\subsection{The causes of trackway construction and abandonment}

At Beckton, the late Neolithic/Early Bronze Age wooden platform and trackway were both constructed on the peat surface at approximately the same depth and date, as seeds from the peat immediately below both structures provide statistically the same age (4230-3890 and 4240-3920 cal BP respectively), although wood from the structures themselves indicate different ages: the maximum age range of wood from the platform is $3980-3580 \mathrm{cal} \mathrm{BP}$, and the younger trackway is $3550-3180 \mathrm{cal} \mathrm{BP}$. Despite the chronological difference, the palaeoenvironmental results, in combination with the stratigraphic position of the structures indicate that both the platform and trackway were built upon a peat surface that had been relatively dry since $5220-4940$ cal BP. However, the peat overlying the trackway exhibits an entirely different hydrological signature, with evidence of increased inundation and retrogressive succession suggesting abandonment in response to wetter conditions. Further evidence for this change in environment was recorded in Trench 2 , in which a substantial quantity of natural waterlogged wood was recorded at the same horizon. At Beckton there appears to have been 
a temporary reversal in this transition towards wetter conditions, with a return to peat formation and Alnus dominated wetland woodland, prior to eventual inundation, most likely between 2700 and 2000 cal BP. The transition towards wetter conditions and inundation was almost certainly driven by estuarine expansion during the late Holocene; the potential causes of which are the subject of much discussion elsewhere (e.g. Sidell, 2000; Shennan et al., 2006; Horton \& Shennan, 2009; Baeteman et al., 2011; Bradley et al., 2011; Shennan et al., 2012).

The results from Beckton would therefore appear to suggest that the structures were built in response to cultural imperatives (for example: maintaining networks and providing access to specific resources; e.g. Meddens, 1996; Plunkett et al., 2013), and abandoned as consequence of environmental change (wetter conditions consequent of increased inundation). However, at other trackway sites where pollen analysis has been undertaken in the Lower Thames Valley, the evidence is less clear. Waller \& Grant (2012) argue that at only Fort Street, Silvertown (Crockett et al., 2002) does the structure pre-date the change in pollen stratigraphy; at three other sites, the occurrences are reversed. In some studies, only the last (surviving) phase of construction has been radiocarbon dated, so the initial phase/s is unknown (Meddens, 1996; Waller \& Grant, 2012). This only enhances an issue raised by Plunkett et al. (2013) based on the study of Irish peatland wooden structures, that on the basis of chronology alone, it can be difficult to positively identify causal relationships between environmental change and the use of peatland structures, and the mechanisms by which environmental change can influence their use are complex.

\subsection{Conclusions}

The new radiocarbon-dated palaeoenvironmental record from Beckton indicates that peat formation commenced at 7190-6620 cal BP and ceased sometime after 3460-3240 cal BP (estimated to be between 2700 and 2000 cal BP). During the period of peat formation, various important environmental changes were recorded in the following chronological order:

1. Quercus and Tilia dominated dryland woodland retreated from the site following submersion by peat and the growth of Alnus carr woodland.

2. Ulmus declined from the dryland woodland during the Neolithic between ca. 6150-6000 and 60305810. Multiple causes are indicated with Ulmus growing under stressed conditions (possibly 
suffering the effects of disease) prior to its decline from the local environment, followed by archaeological and palaeoecological evidence of human activity.

3. Taxus first appeared in the pollen record from 5740-5500, potentially facilitated by openings created in the dryland woodland following temporary land clearance. However, from 5220-4940 cal BP, it underwent an expansion representing its migration onto the peat surface to form mixed carr woodland with Alnus. This colonisation appears to have been dependent upon a dry peat surface linked to a lower rate of relative sea level rise, or possibly favourable climatic conditions. Taxus declined from the wetland between ca. $4410-4220$ and $4160-3930$ cal BP, an event that was at least partially linked to its use in trackway construction during the Bronze Age.

4. Dryland woodland declined from $4160-3930$ cal BP. The cause of the decline appears to be multicausal with unequivocal contemporaneous evidence of activity on the wetland demonstrating interference with the vegetation succession, and an increase in Alnus pollen potentially suggesting the expansion of fen woodland onto areas of former dryland.

5. A platform and trackway appear to have been constructed contemporaneously on the peat surface (4230-3890 cal BP), although the wood used for construction was older in the platform (3980-3580 cal BP) than trackway structure (3550-3180 cal BP). The surface on which construction took place was dry suggesting that construction was not in response to a change in environmental conditions. However, abandonment clearly was, with a transition to wetter conditions eventually culminating in estuarine inundation later in the sequence.

The new investigations at Beckton have therefore provided a significant contribution to our understanding of the interactions between vegetation change and human activity in coastal wetlands. Ongoing research into the history of Taxus, Ulmus and Tilia will continue to improve knowledge and understanding of the timing, duration and causes of vegetation change across the area, as well as comparison with records from other parts of the UK and Europe. The study has also demonstrated the importance of undertaking high resolution multi-proxy palaeoenvironmental investigations proximal to wetland structures in order to elucidate whether construction has taken place in response to environmental change, and the potential for tephrochronological studies in the Lower Thames Valley. 
The research has provided an important contribution to our understanding of the former distribution of Taxus in NW Europe. Its growth on coastal wetlands as part of mixed deciduous woodland has no known modern analogue in the UK, and clearly indicates that its distribution was far more widespread in the past. The study indicates that Taxus was able to grow in a wider range of habitats but is sensitive to the pressures of both environmental change and human activities. Thus, given current concerns over declining population levels, improved measures to conserve and manage Taxus woodland in the UK and many parts of Europe are urgently required to ensure its long-term sustainability.

\section{Acknowledgements}

These investigations were undertaken with the support and funding from Pre-Construct Archaeology Limited (site code: GWB03), Duncan Hawkins of CgMs Consulting and Fairview Homes PLC. CRB's doctoral research was jointly funded by CgMs Consulting and ArchaeoScape (Royal Holloway, University of London). The authors would like to thank the reviewers for their comments on the manuscript, and the following individuals for their help: Dr Jane Sidell (Historic England) and Dr Koen Deforce (Royal Belgian Institute of Natural Sciences).

\subsection{References}

Alexander, K.N.A. (1994) An Annotated Checklist of British Lignicolous and Saproxylic Invertebrates. National Trust Estates Advisors' Office, Ciencester.

Anderberg, A-L. 1994, Atlas of Seeds: Part 4, Swedish Museum of Natural History, Risbergs Trycheri AB, Uddevalla, Sweden.

Andersen, S.Th. (1979) Identification of wild grasses and cereal pollen. Danmarks Geologiske Undersogelse, 1978, 69-92.

Atkinson, T.C., Briffa, K.R. \& Coope, G.R. (1987) Seasonal temperatures in Britain during the past 22,000 years, reconstructed using beetle remains. Nature, 325, 587-592. 
Batchelor, C.R. (2009) Middle Holocene environmental changes and the history of yew (Taxus baccata L.) in the lower Thames Valley. Royal Holloway, University of London Unpublished PhD Thesis.

Batchelor, C.R., Branch, N.P., Allison, E., Austin, P.A., Bishop, B., Brown, A., Elias, S.E., Green, C.P. \& Young D.S. (2014) The timing and causes of the Neolithic elm decline: New evidence from the Lower Thames Valley (London, UK). Environmental Archaeology 19(3), 263-290.

Baeteman, C., Waller, M.P. \& Kiden, P. (2011) Reconstructing middle to late Holocene sea-level change: a methodological review with particular reference to 'A new Holocene sea-level curve for the southern North Sea' presented by Behre. Boreas, 40, 557-572.

Beckett, S.C., \& Hibbert, F.A. (1979) Vegetational change and the influence of prehistoric man in the Somerset levels. New Phytologist, 83, 577-600.

Bengtsson, L. \& Enell, M. (1986) Chemical Analysis. In (Berglund, B.E. ed.) Handbook of Holocene palaeoecology and palaeohydrology, 423-451. Chichester: John Wiley and Sons.

Berggren, G. (1981) Atlas of Seeds: Part 3, Swedish Museum of Natural History, Berlings, Arlöv, Sweden.

Bevan, D. (1987) Forest insects. A guide to insects feeding on trees in Britain. Forestry Commission Handbook 1. London: HMSO.

Blockley, S.P.E., Blaauw, M. Bronk Ramsey, C. \& van der Plicht, J. (2007) Building and testing age models for radiocarbon dates in Lateglacial and Early Holocene sediments. Journal of Quaternary Science, 26(15-16), 1915-1926.

Blockley, S. Pyne-O’Donnell, S.D.F. Lowe, J. Matthews, I. Stone, A., Pollard, A.M., Turney, C.S.M., Molyneux, E.G. (2005) Quaternary Science Reviews 24(16-17), 1952-1960. 
Bradley, S..L., Milne, G.A., Shennan, I. \& Edwards, R. (2011) An improved Glacial Isostatic Adjustment model for the British Isles. Journal of Quaternary Science, 26, 541-552.

Branch, N.P., Batchelor, C.R., Cameron, N.G., Coope, G.R., Densem, R., Gale, R., Green, C.P. \& Williams, A.N. (2012) Holocene environmental changes in the Lower Thames Valley, London, UK: Implications for our understanding of the history of Taxus woodland. The Holocene, 22(10), 11431158.

Branch, N.P., Canti, M.G., Clark, P. \& Turney, C.S.M. (2005a) Environmental archaeology: theoretical and practical approaches. London: Edward Arnold.

Branch, N.P., Green, C.P., Vaughan-Williams, A., Elias, S., Swindle, G., \& Batchelor, C.R. (2005b) Bellot Street, Maze Hill, London Borough of Greenwich (site code: GBL05): environmental archaeological assessment. ArchaeoScape Unpublished Report.

Branch, N.P., Young, D.S., Denton, K., Elias, S.A. and Brown, A. (2009) Archaeological excavations at Littleton Bog, Co. Tipperary, Ireland: Environmental archaeological analysis. Quaternary Scientific unpublished report.

Bronk Ramsey, C. (1995) Radiocarbon calibration and analysis of stratigraphy: the Oxcal program. Radiocarbon, 37(2), 425-430.

Bronk Ramsey, C. (2001) Development of the radiocarbon program Oxcal. Radiocarbon, 43(2a), 355363.

Bronk Ramsey, C. (2007) Deposition models for chronological records. Quaternary Science Reviews, 27(1-2), 42-60.

Bunting, M.J. Gaillard, M.-J., Sugita, S., Middleton, R. \& Brostrõm, A. (2004) Vegetation structure and 
pollen source area. The Holocene, 14, 651-660.

Campbell, I.D. (1999) Quaternary pollen taphonomy: examples of differential redeposition and differential preservation. Palaeogeography, Palaeoclimatology, Palaeoecology, 149, 245-256.

Carew T, Meddens F, Batchelor R et al. (2009) Human-environment interactions at the wetland edge in East London: Trackways, platforms and Bronze Age responses to environmental change. London and Middlesex Archaeological Society 60: 1-34.

Chew, S. (1994) Archaeological excavations at Barking Tescos Development Highbridge Road, Barking: Newham Museum Service Unpublished Report.

Clark, S.H.E. \& Edwards, K. J. (2004) Elm bark beetle in Holocene peat deposits and the northwest European elm decline. Journal of Quaternary Science, 19(6), 525-528.

Crockett, A.D., Allen, M.J. \& Scaife (2002) A Neolithic trackway within peat deposits at Silvertown, London. Proceedings of the Prehistoric Society 68, 185-213.

Daniewski, W.M., Gumulka, M., Anczewski, W., Masnyk, M., Bloszyk, E., \& Gupta, K.K. (1998) Why the yew tree (Taxus baccata) is not attacked by insects. Phytochemistry, 49(5), 1279-1282.

Deforce, K. \& Bastiaens, J. (2007) The Holocene history of Taxus baccata (yew) in Belgium and neighbouring regions. Belgian Journal of Botany, 140(2), 222-237.

Deforce, K., Storme, A., Bastiaens, J., Debruyne, S., Denys, L., Ervynck A., Meylemans, E., Stieperaere, H., Van Neer, W. \& Crombe, P. (2014) Middle-Holocene alluvial forests and associated fluvial environments: A multi-proxy reconstruction. The Holocene, 24, 1550-1564.

Delahunty, J.L. (2002) Religion, war, and changing landscapes: an historical and ecological account of the yew tree (Taxus baccata L.) In Ireland. University of Florida unpublished PhD thesis. 
Devoy, R.J.N. (1979) Flandrian sea-level changes and vegetational history of the lower Thames estuary. Philosophical Transactions of the Royal Society of London, B285, 355-410.

Devoy, R.J.N. (1982) Analysis of the geological evidence for Holocene sea-level movements in southeast England. Proceedings of the Geologists' Association, 93, 65-90.

Divers, D. (1995) Archaeological Excavation of the former Beckton Nursery. Newham Museum Service Unpublished Report.

Divers, D. (1996) Archaeological Investigation of Hays Storage Services LTD, Pooles Lane, Ripple Road, Dagenham, Essex. Newham Museum Service Unpublished Report.

Friday, L.E. (1988) A Key to the Adults of British Water Beetles, Field Studies, 7, 1-151.

Gale, R., \& Cutler, D. (2000) Plants in archaeology: identification manual of vegetative plant materials used in Europe and the southern Mediterranean to c. 1500. Otley: Westbury Academic \& Scientific Publishing.

Gibbard, P. (1995) Palaeogeographical evolution of the lower Thames valley. In (D.R. Bridgland, P. Allen \& B.A. Haggart, eds.) The Quaternary of the lower reaches of the Thames, 5-34. Durham: Quaternary Research Association.

Girling, M.A. (1988) The bark beetle Scolytus scolytus (Fabricius) and the possible role of elm disease in the early Neolithic, In (M. Jones, ed.) Archaeology and the Flora of the British Isles. Oxford University Committee for Archaeology, 14, 34-38.

Girling, M.A. and Grieg, J. (1985) A first fossil record for Scolytus scolytus (F.) (elm bark beetle): its occurrence in elm decline deposits from London and implications for Neolithic elm disease. Journal of Archaeological Science 12, 347-351. 
Godwin, H. (1975) The History of British Flora: Second Edition. Cambridge: Cambridge University Press.

Grant, M.J, Waller, M.P. \& Groves, J.A. (2011) The Tilia decline: Vegetation change in lowland Britain during the mid and late Holocene. Quaternary Science Reviews 30: 394-408.

Grattan, J.P. (1991) Feasibility study, to investigate the potential of analysis of waterlogged materials from marshes of south east England in identification of Anopheles Atroparvus or other invertebrates as a vector in the spread of malaria in this environment. Unpublished University of Sheffield report.

Grimm, E.C. (2004). Tilia2 and TGView. Illinois State Museum, Springfield.

Hageneder, F. (2007) Yew a history. Gloucestershire: Sutton Publishing Ltd.

Hannon, G.E. \& Bradshaw, R.H.W. (1989) Recent vegetation dynamics on two Connemara lake islands, Western Ireland. Journal of Biogeography, 16, 75-81.

Hart, D. (2010) Excavations at Belmarsh West Woolwich. London Archaeologist 12, 203-207.

Hawkins, N. (2005) An archaeological excavation at Bellott Street, Maze Hill, London Borough of Greenwich, SE10. Pre-Construct Archaeology Unpublished Report.

Hjelle, K.L. (1998) Herb pollen representation in surface moss samples from mown meadows and pastures in western Norway. Vegetation History and Archaeobotany, 7, 79-96.

Horton, B. \& Shennan, I. (2009) Compaction of Holocene strata and the implications for relative sea level change on the east coast of England. Geology, 37, 1083-1086.

Huang, C.C. (2002) Holocene landscape development and human impact in the Connemara Uplands, 
Western Ireland. Journal of Biogeography, 29, 153-165.

Huntley, B. \& Birks, H.J.B. (1983) An atlas of past and present pollen maps of Europe: 0-13,000 years ago. Cambridge: Cambridge University Press.

Iszkuło G, Didukh Y, Giertych MJ, Jasińska AK, Sobierajska K \& Szmyt J (2012) Weak competitive ability may explain decline of Taxus baccata. Annals of Forest Science 69: 705-712.

Iskulo, G., Pers-Kamczyc, E., Nalepka, D., Rabska, M., Walas, Ł. \& Dering, M. (2016) Postglacial migration dynamics helps to explain current scattered distribution of Taxus baccata. Dendrobiology, 76, 81-89.

Jarrett, C. (1996). Archaeological evaluation at the East Beckton District Centre. Newham Museum Service Unpublished Report.

Kelly, D.L. (1981) The native forest vegetation of Killarney, South-west Ireland: an ecological account. Journal of Ecology, 69, 437-472.

Koch, K. (1989) Die Käfer Mitteleuropas, Ökologie, 1. Goecke and Evers, Krefeld.

Lakin, D. (1998) Atlas Wharf, Westferry Road, Isle of Dogs. MoLAS unpublished report.

Lane, C.S., Blockley, S.P.E., Mangerud, J., Smith, V.C., Lohne, S., Tomlinson, E.L., Matthews, I.P. \& Lotter, A.F. (2012). Was the 12.1ka Icelandic Vedde Ash one of a kind? Quaternary Science Reviews, 33, 87-99.

Larsen G, Newton AJ, Dugmore AJ, Vilmundardo'ttir E. (2001) Geochemistry, dispersal, volumes and chronology of Holocene silicic tephra layers from the Katla volcanic system, Iceland. Journal of Quaternary Science 16, 119-132. 
Lamb, H. \& Thompson, A. (2005) Unusual mid-Holocene abundance of Ulmus in western Ireland human impact in the absence of a pathogen? The Holocene, 15(3), 447-452.

Lattin, J.D. (1998) A review of the insects and mites found on Taxus spp. with emphasis on western North America. General Technical Report, PNW-GTR-433. USDA Forest Service. Pacific Northwest Research Station, USA.

Linares J.C. (2013) Shifting limiting factors for population dynamics and conservation status of the endangered English yew (Taxus baccata L., Taxaceae). Forest Ecology and Management, 291, 119127.

Lindroth, C.H. (1974) Coleoptera: Carabidae: Handbooks for the Identification of British Insects. Royal Entomological Society of London, 5(2).

Meddens, F.M. (1996) Sites from the Thames Estuary Wetlands, England and their Bronze Age use. Antiquity, 70, 325-334.

Mitchell, F.J.G. (1988) The vegetational history of the Killarney oakwoods, SW Ireland: Evidence from fine spatial resolution pollen analysis. Journal of Ecology, 76, 415-436.

Mitchell, F.J.G. (1990) The history and vegetation dynamics of a yew wood (Taxus baccata L.) in S.W. Ireland. New Phytologist, 115, 573-577.

Molloy, K. \& O'Connell, M. (2004) Holocene vegetation and land-use dynamics in the karstic environment of Inis Oirr, Aran Islands, western Ireland: pollen analytical evidence evaluated in light of the archaeological record. Quaternary International, 113, 41-64.

Moore, P.D., Webb, J.A. \& Collinson, M.E. (1991) Pollen Analysis. Oxford: Blackwell Scientific.

Mysterud, A. \& Østbye, E. (2004) Roe deer (Capreolus capreolus) browsing pressure affects yew 
(Taxus baccata) recruitment within nature reserves in Norway. Biological Conservation, 120, 545-548.

O'Connell, M. \& Molloy, K. (2001) Farming and woodland dynamics in Ireland during the Neolithic. Biology and Environment: Proceedings of the Royal Irish Academy, 101B(1-2), 99-128.

O'Connell, M., Molloy, K. \& Bowler, M. (1988) Post-glacial landscape evolution in Connemara, Western Ireland with particular reference to woodland history. In (H.H. Birks, H.J.B. Birks, P.E. Kaland \& D. Moe, eds.) The cultural landscape: past, present and future, 267-287. Cambridge: Cambridge University Press.

Óladóttir, B.A. Larsen, G. Pórðarson, P \& Sigmarsson, O. (2005) The Katla volcano S-Iceland: Holocene tephra stratigraphy and eruption frequency. JÖKULL, 55, 53-71.

Orme, B.J. \& Coles, J.M. (1989) Prehistoric woodworking from the Somerset Levels: 2. Species selection and prehistoric woodlands. Somerset Levels Papers, 15, 6-24.

Parker, A.G., Goudie, A.S., Anderson, D.E., Robinson, M.A. \& Bonsall, C. (2002) A review of the midHolocene elm decline in the British Isles. Progress in Physical Geography, 26(1), 1-45.

Peglar, S.M. \& Birks, H.J.B. (1993) The mid-Holocene Ulmus fall at Diss Mere, south-east England disease and human impact? Vegetation history and Archaeobotany, 2, 61-68.

Pepys, S. (1665). Samuel Pepys Diary September 1665. Available at http://www.pepysinfo/1665/ 1665sep.html accessed on 20 $20^{\text {th }}$ April 2007.

Perez, M., Fyfe, R.M., Charman, D.J. \& Gehrels, R. (2015) Later Holocene vegetation history of the Isles of Scilly, UK: coastal influence and human land use in a small island context. Journal of Quaternary Science, 30, 764-778. 
Perry, I. \& Moore, P.D. (1987) Dutch elm disease as an analogue of Neolithic elm decline. Nature, 326, $72-73$.

Philip, B. \& Garrod, D. (1994) A prehistoric wooden trackway at Greenwich. Kent Archaeological Review 117, 147-168.

Plunkett, G., McDermott, C., Swindles, G.T., Brown, D.M. (2013) Environmental indifference? A critique of environmentally deterministic theories of peatland archaeological site construction in Ireland. Quaternary Science Reviews, 61, 17-31.

Reille, M. (1992) Pollen et spores D'Europe et D'Afrique du Nord. Laboratoire de Botanique historique et Palynologie, Marsaille.

Reimer, P.J., Bard, E., Bayliss, A., Beck, J.W., Blackwell, P.G., Bronk Ramsey, C., Grootes, P.M., Guilderson, T.P., Haflidason, H., Hajdas, I., HattŽ, C., Heaton, T.J., Hoffmann, D.L., Hogg, A.G., Hughen, K.A., Kaiser, K.F., Kromer, B., Manning, S.W., Niu, M., Reimer, R.W., Richards, D.A., Scott, E.M., Southon, J.R., Staff, R.A., Turney, C.S.M., \& van der Plicht, J. (2013). IntCal13 and Marine13 Radiocarbon Age Calibration Curves 0-50,000 Years cal BP. Radiocarbon, 55(4), 1869-1887.

Ruprecht H, Dhar A, Aigner B, Oitzinger G, Klumpp R \& Vacik H (2010) Structural diversity of English yew (Taxus baccata L.) populations. European Journal of Forest Research, 129, 189-198.

Robinson M. (2000) Coleopteran evidence for the elm decline, Neolithic activity in woodland, clearance and the use of the landscape, pp. 27-36 in Fairburn AS (ed.) Plants in Neolithic Britain and Beyond. Neolithic Studies Group Seminar. Papers 5 Oxbow Books: Oxford.

Scaife, R.G. (1988) The elm decline in the pollen record of South-east England and its relationship to early agriculture. In (M. Jones, ed.) Archaeology and the flora of the British Isles, 21-33. Oxford University Committee for Archaeology. 
Scaife, R.G. (2001) East Ham FC, Pennyroyal Avenue, Beckton, London E6, an Environmental Assessment. Unpublished HAT Report 903.

Seel, S.P.S. (2001) Late Prehistoric woodlands and wood use on the Lower Thames floodplain. University College, London: Unpublished PhD thesis.

Shennan, I., Bradley, S., Milne, G., Brooks, A., Bassett, S. \& Hamilton, S. (2006) Relative sea-level changes, glacial isostatic modelling and ice-sheet reconstructions from the British Isles since the Last Glacial Maximum. Journal of Quaternary Science, 21, 585-599.

Shennan, I., Milne, G. \& Bradley, S. (2012) Late Holocene vertical land motion and relative sea-level changes: lessons from the British Isles. Journal of Quaternary Science, 27, 64-70.

Sidell, E.J. (2003) Relative sea-level change and archaeology in the inner Thames estuary during the Holocene. University College, London, Unpublished PhD Thesis.

Smith, A.G. (1981) The Neolithic. In (I.G. Simmonds \& M.J. Tooley, eds.) The environment in British prehistory, 125-209. London: Duckworth.

Stace, C. (1997) New Flora of the British Isles. Cambridge: Cambridge University Press.

Stafford, E. (2012).Landscape and Prehistory of the East London Wetlands. Investigations along the A13 DBFO Roadscheme, Tower Hamlets, Newham and Barking and Dagenham, 2000-2003. Oxford Archaeology Monograph 17.

Stuiver M. \& Reimer, P.J. (1986) A computer program for radiocarbon age calculation. Radiocarbon, 28(2B), 1022-1030.

Svenning JC \& Magärd E (1999) Population ecology and conservation status of the last natural population of English yew (Taxus baccata) in Denmark. Biological Conservation 88: 173-182. 
Tamblyn, W.S. (1994) Archaeological evaluation of Beckton areas A and B Tollgate Road, Beckton, London Borough of Newham. Newham Museum Service Unpublished Report.

Thomas, P.A. \& Polwart, A. (2003) Taxus baccata L. Journal of Ecology, 91, 489-524.

Thomas, C. \& Rackham, D.J. (1996) Bramcote Green, Bermondsey: a Bronze Age trackway and palaeoenvironmental assessment. Proceedings of the Prehistoric Society, 61, 221-253.

Tittensor, R.M. (1980) Ecological History of Yew Taxus baccata L. in Southern England. Biological Conservation, 17, 243-265.

Troels-Smith, J. (1955). Characterisation of unconsolidated sediments. Danmarks Geologiske Undersøgelse, Raekke IV(3), 38-73.

Truckle, N. \& Sabel, K. (1994) Beckton Alps Ski Slope, Newham Way, East Ham E6, London Borough of Newham. Newham Museum Service Unpublished Report.

Waller, M.P. (1994a) The Fenland Project, number 9: Flandrian environmental change in Fenland. East Anglian Archaeology, Cambridgeshire County Council.

Waller, M.P. (1994b) Paludification and pollen representation: the influence of wetland size on Tilia representation in pollen diagrams. The Holocene, 4, 430-434.

Waller, M.P. (1998) An investigation in the palynological properties of fen peat through multiple pollen profiles from south-eastern England. Journal of Archaeological Science 25, 631-642.

Waller, M.P. (2013) Drought, disease, defoliation and death: forest pathogens as agents of past vegetation change. Journal of Quaternary Science 28(4), 336-342. 
Waller, M.P. \& Early, R. (2015) Vegetation dynamics from a coastal peatland: insights from combined plant macrofossil and pollen data. Journal of Quaternary Science, 30, 779-789.

Waller, M. \& Grant, M.J. (2012) Holocene pollen assemblages from coastal wetlands: differentiating natural and anthropogenic causes of change in the Thames estuary, UK. Journal of Quaternary Science, 27(5) 461-474.

Waller, M.P., Binney, H.A., Bunting, M.J. \& Armitage, R.A. (2005) The interpretation of fen carr pollen diagrams: pollen-vegetation relationships within fen carr. Review of Palaeobotany and Palynology, 133, 179-202.

Wheeler, B.D. (1980) Plant communities of rich-fen systems in England and Wales III: fen meadow, fen grassland and fen woodland communities, and contact communities. Journal of Ecology, 68, 761788.

Wilkinson, T.J. (1988) Archaeology and environment in South Essex: rescue archaeology along the Grays by-pass, 1979/80, Number 42. East Anglian Archaeology.

Wilkinson, T.J. \& Murphy, P.L. (1995) The archaeology of the Essex coast, volume 1: The Hullbridge Survey. East Anglian Archaeology.

Wilkinson, K.N., Scaife, R.J. \& Sidell, E.J. (2000) Environmental and sea-level changes in London from 10,500 BP to the present: a case study from Silvertown. Proceedings of the Geologists' Association, 111, 41-54.

Young, D.S., Branch, N.P., Denton, K., Elias, S.A. and Brown, A. (2009) Archaeological excavations at Kinnegad Bog, Co. Meath, Ireland: Environmental archaeological analysis. Quaternary Scientific unpublished report. 
Young, D.S., Stastney, P., Branch, N.P., Black, S. and Elias, S.A. (2011) Archaeological excavations at Longford Pass Bog, Co. Tipperary, Ireland: Environmental archaeological analysis. Quaternary Scientific unpublished report.

Young, D.S., Stastney, P., Branch, N.P., Black, S. and Elias, S.A. (2012) Archaeological excavations at Castlegar Bog, Co. Galway, Ireland: Environmental archaeological analysis. Quaternary Scientific unpublished report. 